\title{
Implementasi Kebijakan Sistem Online Single Submission (OSS) Pada Dinas Penanaman Modal dan Pelayanan Terpadu Satu Pintu (DPMPTSP) di Kabupaten Subang
}

\author{
Iwan Henri Kusnadi \\ Fakultas Ilmu Administrasi Universitas Subang \\ Iwanhenri01@gmail.com \\ Muhammad Rifqi Baihaqi \\ Fakultas Ilmu Administrasi Universitas Subang \\ baihaqirifqi32@gmail.com
}

\begin{abstract}
Abstrak
Pada umumnya pemerintah daerah mempunyai kewajiban dalam menyelenggarakan pelayanan yang lebih baik kepada masyarakat. Dalam rangka menyelenggarakan hal tersebut pemerintah daerah telah mengeluarkan kebijakan yang bertujuan untuk mengefektifkan, mengefisiensikan dan mendekatkan pelayanan kepada masyarakat. Salah satu kebijakannya yaitu kebijakan Peraturan Presiden Republik Indonesia nomor 24 tahun 2018 tentang Pelayanan Perizinan Berusaha Terintegrasi Secara Elektronik. Kebijakan Sistem Online Single Submission (OSS) dilaksanakan dengan tujuan untuk membantu para pelaku usaha yang ingin membuat izin usahanya agar lebih mudah. Diharapkan dengan di terapkannya perizinan melalui Online Single Submission (OSS) akan memberikan dampak yang lebih baik lagi dan memberikan kepuasan bagi masyarakat. Penelitian ini menggunakan metode pendekatan kualitatif. Ruang lingkup penelitian ini yaitu dinas penanaman modal dan pelayanan terpadu satu pintu kabupaten suban. Yang menjadi sumber informasi (informan) yaitu penanggung jawab dari pemerintah daerah, dalam hal ini pihak yang terkait adalah pegawai pemerintah daerah (PEMDA) di bagian pemerintahan dan bidang pengembangan sistem informasi Online Single Submission di Dinas Penenaman Modal Dan Pelayanan Terpadu Satu Pintu Kabupaten Subang. Pengumpulan data dilakukan dengan teknik observasi, wawancara dan dokumentasi. Data yang diperoleh kemudian di analisa menggunakan teknik triangulasi, kemudian di susun secara sistematis sehingga pada tahap penarikan kesimpulan bersifat intepretatif. Hasil penelitian menunjukan implementasi sistem online single submission belum berjalan efektif sehingga tujuan dari OSS untuk meningkatkan kualitas dan mendekatkan pelayanan kepada masyarakat belum efektif dan efisien.
\end{abstract}

Kata kunci: implementasi kebijakan, OSS 


\section{Abstract}

In general, local governments have an obligation to provide better services to the community. In the framework of carrying out this matter the regional government has issued a policy that aims to streamline, streamline and bring services to the public. One of the policies is the Republic of Indonesia Presidential Regulation number 24 of 2018 concerning Electronically Integrated Business Licensing Services. The Online Single Submission System (OSS) policy is implemented with the aim of helping business people who want to make their business licenses easier. It is hoped that licensing through the Online Single Submission (OSS) will have a better impact and provide satisfaction for the community. This research uses a qualitative approach. The scope of this research is the one-stop investment and integrated services department in Suban Regency. The source of information (informant) is the person in charge of the regional government, in this case the relevant party is a local government employee (PEMDA) in the government department and in the field of developing an Online Single Submission information system at the One-Stop Investment and Integrated Services Office of Subang Regency. Data collection is done by observation, interview and documentation techniques. The data obtained are then analyzed using triangulation techniques, then arranged systematically so that the conclusions drawn are interpretative. The results showed that the implementation of a single online submission system was not yet effective, so the purpose of the OSS was to improve the quality and bring services closer to the public that had not been effective and efficient.

Keywords: policy implementation, OSS

\section{Pendahuluan}

Panjangnya waktu dan rantai birokrasi yang harus dilewati untuk memulai suatu usaha membuat para pelaku usaha enggan mendaftarkan usaha yang di milikinya, hal tersebut mendorong pemerintah melakukan reformasi struktural, termasuk dengan reformasi sistem perizinan dengan Penerapan Pelayanan Terpadu Satu Pintu (PTSP) dan Online Single Submission (OSS) Pemerintah sudah menjalankan Online Single Submission (OSS) sebagai sistem yang mengintegrasikan seluruh pelayanan perizinan berusaha yang menjadi kewenangan Menteri/Pimpinan Lembaga, Gubernur, atau Bupati/Walikota yang dilakukan secara elektronik. Melalui reformasi sistem perizinan, pemerintah mendorong standarlisasi menjadikan birokrasi perizinan di tingkat pusat dan daerah lebih mudah, lebih cepat, dan juga lebih terintegrasi dengan demikian di keluarkanlah Peraturan Presiden Republik Indonesia Nomor 24 Tahun 2018 tentang Pelayanan Perizinan Berusaha Terintegrasi Secara elektronik.

Berdasarkan Peraturan Pemerintah Republik Indonesia No. 24/2018 tentang Pelayanan Perizinan Berusaha Terintegrasi Secara Elektronik, Ditegaskan bahwa Pelaksanaan kewenangan penerbitan Perizinan Berusaha sebagaimana dimaksud, 


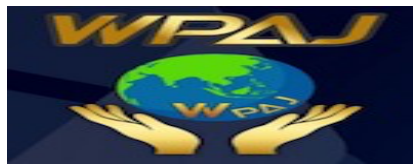

termasuk penerbitan dokuman lain yang berkaitan dengan Perizinan Berusaha wajib dilakukan melalui Lembaga OSS ( Pasal 19 PP No. 24/2018 ).

Kabupaten Subang sebagian besar penduduknya masih berpenghasilan utama sebagai petani dan buruh perkebunan, akan tetapi seiring dengan perkembangan globalisasi tidak sedikit investor yang tertarik menanamkan modal untuk usahanya di Kabupaten Subang, diantaranya seperti mendirikan pabrik, store/toko, restaurant dll. Dengan demikian para pelaku usaha dan investor yang ingin membuka atau menanamkan modal nya harus mendapatkan izin terlebih dahulu dari pihak dinas penanaman modal pelayanan terpadu satu pintu kabupaten subang. Sebelum di turunkannya Peraturan Pemerintah Republik Indonesia No. 24/2018 para pelaku usaha dan para investor harus mendatangi kantor pihak dinas penanaman modal pelayanan terpadu satu pintu kabupaten subang untuk mendaftarkan usahanya, tetapi setelah dikeluarkannya Peraturan Pemerintah Republik Indonesia No. 24/2018 tentang Pelayanan Perizinan Berusaha Terintegrasi Secara Elektronik, Ditegaskan bahwa Pelaksanaan kewenangan penerbitan Perizinan Berusaha sebagaimana dimaksud, termasuk penerbitan dokuman lain yang berkaitan dengan Perizinan Berusaha wajib dilakukan melalui Lembaga OSS ( Pasal 19 PP No. 24/2018 ) dan diberlakukan sejak januari 2018, Seluruh permohonan perizinan dilakukan dengan atau melalui lembaga OSS.

Dinas Penanaman Modal dan Pelayanan Terpadu Satu Pintu (DPMPTSP) Kabupaten Subang memiliki fasilitas yang memadai untuk mendukung penerapan sistem online single submission yang dimana Dinas Penanaman Modal Dan Pelayanan Terpadu Satu Pintu Kabupaten Subang memiliki fasilitas seperti komputer untuk membantu mempermudah para pelaku usaha yang tidak memiliki komputer/gadget sebagai sarana untuk mendaftarkan usahanya, pihak DPMPTSP juga akan membantu serta membimbing para pelaku usaha dalam hal pendaftaran usahanya tersebut. Berdasarkan penjajagan di lapangan pelaksanaan peng integrasian sistem Online Single Submission Di Dinas Penenaman Modal Dan Pelayanan Terpadu Satu Pintu Kabupaten Subang masih ditemukan adanya permasalahan sebagai berikut :

1. Kurangnya sosialisasi terhadap masyarakat tentang sistem online single submission hanya sebagian kecil dari masyarakat yang di berikan sosialisasi terhadap sistem OSS, seperti IAI (Ikatan Apoteker Indonesia) kabupatan subang, IDI (Ikatan Dokter Indonesia) kabupaten subang dan sosialisasi itupun hanya satu kali digelar dalam kurun waktu satu tahun dari tahun 2018 sejak PP tersebut keluar hingga 2019 sekarang, hal itu menjadikan banyaknya masyarakat yang belum mengetahui apa itu OSS sehingga pada saat seorang pelaku usaha ingin membuat izin usaha untuk usaha yang dimilikinya, pelaku usaha tersebut bingung saat proses pembuatan izin usaha tersebut, karena proses yang harus dilakukan oleh pelaku usaha yang ingin membuat surat izin usaha berbeda dengan sebelumnya jikalau dulu seorang izin usaha menyiapkan persyaratan terlebih dahulu untuk proses pembuatan izin baru pelaku usaha dapat mendaftarkan usahanya tersebut dan bila persyaratan telah dianggap cukup maka keluarlah surat izin usahanya, tetapi dalam proses pembuatan izin sekarang pelaku usaha harus mendaftarkan terlebih dahhulu usahanya melalui sistem OSS untuk mendapatkan NIB ( nomor induk berusaha ) baru setelah pelaku usaha mendapatkan NIB pelaku usaha dapat melanjutkan ke tahap selanjutnya dengan 
membuat persyaratan-persyaratan pembuatan izin usaha. Akan tetapi sistem OSS sendiri masih belum terimplementasi dengan baik karena dalam pembuatan izin usaha ini, para pelaku usaha harus tetap atau masih mendatangi kantor dinas penanaman modal dan pelayanan terpadu satu pintu untuk melanjutkan proses pembuatan izin tersebut. dengan demikian adanya sistem OSS tersebut tidak meringkas atau memotong rantai birokrasi sebagaimana tujuan utama dari sistem tersebut, dengan adanya sistem tersebut malah membuat dan menambah panjangnya rantai birokrasi yang mulanya hanya perlu melewati satu meja untuk pembutan izin (jika persyaratan sudah lengkap ) sekarang pelaku usaha harus melewati lebih dari satu meja untuk pembuatan izin tersebut.

2. Kurangnya pemahaman aparatur terhadap sistem OSS karena ketika seorang pelaku usaha menanyakan tentang OSS hanya bagian bagian tertentu yang dapat menjelaskannya yang dimana seharusnya para aparatur yang bekerja di dinas yang bersangkutan dengan OSS apalagi aparatur tersebut bekerja di bagian tertentu yang bersangkutan dengan sistem tersebut harus lebih memahami tentang sistem OSS.

\section{Kerangka Teori}

Kebijakan Publik

Pengertian kebijakan secara etimologi berasal dari kata yunani dan latin yaitu "polis" yang dalam Bahasa inggris kemudian berubah menjadi "policy" yang diterjemahkan dalam Bahasa Indonesia menjadi kebijakan. Menurut kamus besar Bahasa Indonesia, pengertian kebijakan adalah rangkaian konsep dan menjadi pedoman dan dasar rencana dalam pelaksanaan suatu pekerjaan, kepemimpinan, dan cara bertindak. Istilah ini dapat diterapkan pada pemerintah, organisasi dan kelompok ,sektor,swasta, serta individu. Kebijakan berbeda dengan peraturan dan hukum. Kebijakan merupakan pengarah terhadap kegiatan pembangunan yang dilakukan oleh pemerintah, swasta maupun masyarakat. Manusia memiliki peranan yang sangat penting dalam pelaksanaan kebijakan, sebab manusia dapat berperan sebagai aparatur pemerintah dan pelaksanaan kegiatan dalam pembangunan. Menurut Federick sebagaimana dikutip dalam Agustino (2008:7) mendefinisikan: Kebijakan sebagai serangkaian tindakan/kegiatan yang diusulkan seseorang kelompok atau pemerintah dalam suatu lingkungan tertentu dimana terdapat hambatan-hambatan (kesulitan-kesulitan) dan kesempatan-kesempatan terhadap pelaksanaan usulan kebijaksanaan tersebut dalam rangka mencapai tujuan tertentu. Pendapat ini juga menunjukan bahwa ide kebijakan melibatkan perilaku yang memiliki maksud dan tujuan merupakan bagian yang penting dari definisi kebijakan, karena bagaimana kebijakan harus menunjukan apa yang sesungguhnya dikerjakan dari pada apa yang diusulkan dalam beberapa kegiatan pada suatu masalah. mempunyai maksud/tujuan tertentu yang diikuti dan dilaksanakan oleh seorang aktor atau sekelompok aktor yang berhubungan dengan suatu permasalahan atau suatu hal yang diperhatikan". Konsep kebijakan ini menitikberatkan pada apa yang sesungguhnya dikerjakan daripada apa yang diusulkan atau dimaksud. Dan hal yang membedakan kebijakan dari suatu keputusan yang merupakan pilihan diantara alternatif yang ada.Menurut 


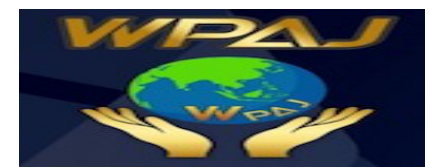

Anderson dalam Agustino (2017:17): Kebijakan Publik adalah serangkaian kegiatan yang mempunyai tujuan tertentu yang di ikuti dan dilaksanakaan oleh seorang atau sekelompok aktor yang berhubungan dengan permasalahan atau sesuatu hal yang diperhatikan.

Proses pembuatan kebijakan merupakan proses kompleks karena melibatkan banyak proses maupun variabel yang harus dikaji. Untuk itu, agar lebih mudah dalam mengkaji kebijakan publik maka diperlukan beberapa tahap. Adapun tahapan tersebut Menurut Dunn dalam Winarno (2007:35-37) sebagai berikut:

1. Tahap Penyusunan Agenda

Para pejabat yang pilih dan diangkat menempatkan masalah pada agenda publik. Sebelumnya masalah-masalah berkompetisi terlebih dahulu untuk dapat masuk ke dalam agenda kebijakan. Pada akhirnya, beberapa masalah masuk ke agenda kebijakan para perumusan kebijakan

2. Tahap Formulasi Kebijakan

Masalah telah masuk ke agenda kebijakan kemudian dibahas oleh para pembuat kebijakan. Masalah-masalah tadi didefinisikan untuk kemudian dari pemecahan masalah terbaik. Pemecahan masalah tersebut berasal dari berbagai alternative atau pilihan kebijakan (policy alternatives/policy options) yang ada sama hanya dengan perjuangan suatu masalah untuk masuk kedalam agenda kebijakan

3. Tahap Adopsi Kebijakan

Dari sekian alternatif kebijakan yang ditawarkan oleh para perumus kebijakan, pada akhirnya salah satu alternatif kebijakan tersebut diadopsi dengan dukungan dari mayoritas legislatif, konsensus antara direktur lembaga atau keputusan peradilan

4. Tahapan Implementasi Kebijakan

Suatu program kebijakan hanya akan menjadi catatan elit, jika program tersebut tidak implementasi. Oleh karena itu, keputusan program kebijakan yang telah ada diambil sebagai alternatif pemecahan masalah harus diimplementasikan, yakni dilaksanakan oleh badan administrasi maupun agen-agen pemerintah ditingkat bawah.

5. Tahap Formulasi Kebijakan

Masalah telah masuk ke agenda kebijakan kemudian dibahas oleh para pembuat kebijakan. Masalah-masalah tadi didefinisikan untuk kemudian dari pemecahan masalah terbaik. Pemecahan masalah tersebut berasal dari berbagai alternative atau pilihan kebijakan (policy alternatives/policy options) yang ada sama hanya dengan perjuangan suatu masalah untuk masuk kedalam agenda kebijakan

6. Tahap Adopsi Kebijakan

Dari sekian alternatif kebijakan yang ditawarkan oleh para perumus kebijakan, pada akhirnya salah satu alternatif kebijakan tersebut diadopsi dengan dukungan dari mayoritas legislatif, konsensus antara direktur lembaga atau keputusan peradilan

7. Tahapan Implementasi Kebijakan

Suatu program kebijakan hanya akan menjadi catatan elit, jika program tersebut tidak implementasi. Oleh karena itu, keputusan program kebijakan yang telah ada diambil sebagai alternatif pemecahan masalah harus diimplementasikan, yakni 
dilaksanakan oleh badan administrasi maupun agen-agen pemerintah ditingkat bawah.

8. Tahap Evaluasi Kebijakan

Pada tahap ini kebijakan yang telah dijabarkan akan dinilai atau evaluasi untuk melihat sejauh mana kebijakan yang dibuat telah mampu memecahkan masalah.

Kebijakan publik yang dimaksud di buat oleh badan merupakan suatu kebijakan apabila telah dibuat, maka harus diimplementasikan untuk melaksanakan oleh unit administrasi yang memobilitas sumber daya finansial dan manusia, serta dievaluasikan agar dapat dijadikan sebagai mekanisme pengawasan terhadap kebijakan tersebut sesuai dengan kebijakan itu sendiri.

\section{Implementasi Kebijakan}

Kata implementasi berasal dari kata Bahasa inggris yaitu to implement, yang artinya mengimplementasikan atau juga implementasi diartikan sebagai pelaksana atau penerapan. Implementasi merupakan penyediaan sarana untuk melaksanakan sesuatu yang menimbulkan dampak atau akibat itu dapat berupa undang-undang, peraturan pemerintah, keputusan peradilan dan kebijakan yang dibuat oleh lembaga pemerintah dalam kehidupan kenegaraan. Menurut Ripley dan Frankin dalam (Winarno 2012:148) berpendapat bahwa: Implementasi adalah apa yang terjadi setelah undang-undang ditetapkan yang memberikan otoritas program, kebijakan, keuntungan (benefit) atau suatu jenis keluaran yang nyata (tangible-output)".

Istilah implementasi kebijakan menunjukan pada sejumlah kegiatan yang mengikuti pernyataan maksud tentang tujuan-tujuan program dan hasil-hasil yang diinginkan oleh para pejabat pemerintah. Lebih jauh lagi implementasi mencangkup banyak macam kegiatan, pertama, bertanggung jawab dalam melaksanakan program. Kedua , badan-badan pelaksana mengembangkan bahasan anggaran dasar menjadi arahanarahan konkret,regulasi serta rencana-rencana dan desain program. Ketiga, badanbadan pelaksana harus mengorganisasian kegiatan kegiatan mereka dengan meciptakan kegiatan-kegiatan birokrasi dan rutinitas untuk mengatasi beban kerja. Perlu di perhatikan bahwa beberapa pelayanan dapat diberikan tanpa mempunyai dampak substansial pada masalah yang di perkirakan berhubungan dengan kebijakan. Suatu kebijakan mungkin diimplementasikan secara efektif tetapi gagal memperoleh dampak substansial karena kebijakan tidak disusun dengan baik atau karena keadaan-keadaan lainnya. Oleh karena itu, pelaksanaan program yang berhasil merupakan kondisi yang diperlukan sekalipun tidak cukup bagi pencapaian hasil akhir positif. Hal ini berati bahwa implementasi kebijakan hanya merupakan salah satu variable penting yang berpengaruh terhadap keberhasilan suatu kebijakan dalam memecahkan persoalan-persoalan publik.

Kebijakan secara etimologi, istilah kebijakan berasal dari Bahasa Inggris "policy". Akan tetapi, kebanyakan orang berpandangan bahwa istilah kebijakan senantiasa disamakan dengan istilh kebijaksanaan. Padahal apabila dicermati berdasarkan tata Bahasa,isitilah kebijaksanaan berasal dari kata "wisdom". Peneliti berpandangan bahwa istilah kebijakan berbeda dengan istilah kebijaksanaan. Hal ini didasarkan pada pertimbangan bahwa pengertian kebijaksanaan memerlukan pertimbanganpertimbangan yang lebih lanjut, sedangkan kebijakan mencangkup peraturan- 


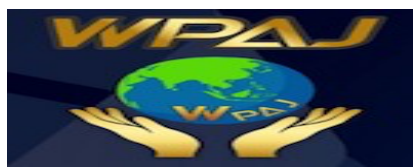

peraturan yang ada didalamnya termasuk konteks politik. Kebijakan Menurut Federick dalam Wahab (2004:3) bahwa “Kebijakan adalah suatu tindakan yang mengarah pada tujuan yang disusulkan oleh seseorang, kelompok atu pemerintah dalam lingkungan tertentu sehubungan dengan adanya hambatan-hambatan tertentu secara mencari peluang untuk mencapai tujuan atau sasaran yang diinginkan".

Kebijakan mengandung suatu unsur tindakan untuk mencapai tujuan dan umumnya tujuan tersebut ingin dicapai oleh seseorang kelompok ataupun pemerintah. Kebijakan tentu mempunyai hambatan-hambatan tetapi harus mencari peluangpeluang untuk mewujudkan tujuan dan sasaran yang di inginkan. Hal ini tersebut berarti kebijakan tidak boleh bertentangan dengan nilai-nilai dan praktik-praktik sosial yang ada dalam masyarakat. Apabila kebijakan berisi nilai-nilai yang bertentangan dengan nilai-nilai yang hidup dalam masyarakat, maka kebijakan harus mampu mengakomodasikan nilai-nilai dan praktik-praktik yang hidup dan berkembang dalam masyarakat.

Implementasi kebijakan secara sederhana dapat diartikan sebagai proses menerjemahkan peraturan ke dalam bentuk tindakan. Dalam praktiknya implementasi kebijakan merupakan suatu proses yang begitu kompleks bahkan tidak jarang bermuatan politis karena wujudnya intervensi berbagai kepentingan. Kebijakan Menurut Metter dan Horn dalam Agustino (2008:195) menjelaskan bahwa Implementasi kebijakan adalah tindakan-tindakan yang dilakukan baik oleh individu-individu/ pejabat-pejabat atau kelompok-kelompok pemerintah atau swasta yang diarahkan pada tercapainya tujuan-tujuan yang telah digariskan dalam keputusan kebijaksanaan.

Berdasarkan rumusan implementasi kebijakan sebagaimana dikemukakan diatas, dapat diketahui bahwa implementasi kebijakan berkaitan dengan tiga hal, yakni :

1. Adanya tujuan atau sasaran

2. Adanya aktivitas

3. Adanya hasil

Namun hal ini saja belum cukup. Ini karena implementasi merupakan proses yang dinamis, dimana pelaksana kebijakan melakukan suatu aktivitas atau kegiatan sehingga pada akhirnya akan mendapatkan suatu hasil yang sesuai dengan tujuan atau sasaran kebijakan itu sendiri.sementara itu keberhasilan suatu implementasi kebijakan dapat diukur atau dilihat dari proses dan pencapaian tujuan hasil akhir (output), yaitu, tercapai atau tidaknya tujuan-tujuan yang ingin diraih. Pengukuran keberhasilan suatu implementasi kebijakaan dapat dilihat dari prosesnya dengan mempertanyakan apakah pelaksanaan program sesuai dengan yang telah ditentukan, yaitu melihat pada action program dari individual projects dan apakah tujuan program tersebut tercapai. Impelmentasi kebijakan merupakan tahapan yang sangat penting dalam keseluruhan struktur kebijakan karena melalui prosedur inilah suatu masalah publik dapat diselesaikan atau tidak. Seperti yang dikatakan oleh udoji (1981:23) dalam Agustino (2017:129) : "the execution of policies is as, important if not more important than policy-making. Policies will remain dreams or blue print file jackets uses there are implemented" Yang diterjemahkan : implementasi kebijakan adalah sesuatu yang penting bahkan mungkin jauh lebih penting dari pada formulasi kebijakan. 


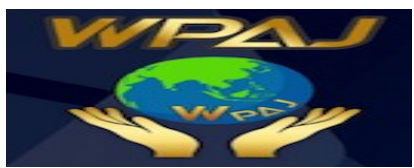

Volume 2 Issue 2, Desember 2020

http://ejournal.unsub.ac.id/index.php/publik

Kebijakan-kebijakan hanya akan sekedar berupa impian atau rencana bagus yang tersimpan rapi dalam arsip kalau tidak dilaksanakan.

\section{Model Implementasi Kebijakan \\ Model Top Down}

Model Top Down adalah model pendekatan secara satu pihak dari atas kebawah dalam proses implementasi peranan pemerintah sangat besar. Pada pendekatan ini asumsi yang terjadi adalah para pembuat keputusan merupakan aktor kunci dalam keberhasilan implementasi, sedangkan pihak-pihak lain yang terlibat dalam proses implementasi di anggap menghambat, sehingga para pembuat keputusan meremehkan inisiatif strategi yang bersal dari level birokrasi rendah maupun subsistem-subsistem kebijaksanaan yang lain.

Ada beberapa model implementasi top down, diantaranya :

Model George C.Edward III

Menurut George Chales Edward III dalam ( Leo Agustino, 2017:137) implementasi kebijakan sebagai suatu proses yang dinamis, dimana terdapat banyak faktor yang saling berinteraksi dan mempengaruhi kebijakan. Faktor-faktor tersebut perlu tampilkan guna mengetahui bagaimana pengaruh faktor-faktor tersebut tersebut terhadap implementasi. Faktor-faktor yang mempengaruhi keberhasilan atau kegagalan implementasi kebijakan. yaitu faktor (1) Komunikasi, (2) Sumber Daya (3) Disposisi (4) struktur birokrasi.

1. Komunikasi

Komunikasi menurut lebih lanjut, sangat menentukan keberhasilan pencapaian tujuan dari implementasi kebijakan publik. Implementasi yang efektif terjadi apabila para pembuat keputusan sudah mengetahui apa yang akan mereka kerjakan, pengetahuan atas apa yang mereka kerjakan dapat berjalan bila komunikasi berjalan dengan baik, sehingga setiap keputusan kebijakan dan peraturan implementasi harus ditransmisikan (atau dikomunikasikan) kepada bagian personalia yang tepat, selain itu kebijakan yang dikomunikasikan pun harus tepat,akurat, dan konsisten. Komunikasi (atau pentransmisian informasi) diperlukan agar pembuat keputusan di dan para implementor akan semakin konsisten dalam melaksanakan kebijakan yang akan diterapkan dalam masyarakat.

Terdapat tiga indikator yang dapat di pakai atau digunakan dalam mengukur keberhasilan variabel komunikasi tersebut:

a. Transmisi

Penyaluran komunikasi yang baik akan dapat menghasilkan suatu implementasi yang baik pula. Seringkali terjadi dalam penyaluran komunikasi adalah adanya salah pengertian (miskomunikasi) hal tersebut disebagiankan karena komunikasi telah melalui beberapa tingkatan birokrasi, sehingga apa yang diharapkan terdistorsi ditengah jalan

b. Kejelasan

Komunikasi yang terima oleh para pelaksanaan kebijakan (street-level-bureuacrats) haruslah jelas dan tidak membingungkan (tidak ambigu/mendua). Ketidakjelasan pesan kebijakan tidak selalu menghalangi implementasi, pada tataran tertentu, para pelaksana membutuhkan fleksibilitas dalam melaksakan kebijakan. Tetapi 
pada tataran yang lain hal tersebut justru akan menyelewengkan tujuan yang hendak dicapai oleh kebijakan yang tetah ditetapkan.

c. Konsistensi

Perintah yang diberikan dalam pelaksanaan suatu komunikasi haruslah konsisten dan jelas, karena jika perintah yang diberikan sering berubah-ubah maka dapat menimbulkan kebingungan bagi pelaksana dilapangan

2. Sumber Daya

Sumber daya merupakan hal yang terpenting lainnya, dalam mengimplementasikan kebijakan. Indikator sumber-sumber daya terdiri dari beberapa elemen yaitu:

a. Staf

Sumber daya utama dalam implementasi kebijakan adalah staf. Kegagalan yang sering terjadi dalam implementasi kebijakan salah satunya disebagiankan oleh karena staf yang tidak mencukupi, memadai, ataupun tidak kompeten dibidangnya. Penambahan jumlah staf dan implementor saja tidak mencukupi, tetapi diperlukan pula kecukupan staf dengan keahlian dan kemampuan yang diperlukan (kompeten dan kapabel) dalam mengimplementasikan kebijakan atau melaksanakan tugas yang diinginkan oleh kebijakan itu sendiri.

b. Informasi

Dalam implementasikan kebijakan, informasi mempunyai dua bentuk, yaitu pertama informasi yang berhubungan dengan cara melaksakan kebijakan, implementor harus mengetahui apa yang harus mereka lakukan disaat mereka diberi perintah untuk melakukan tindakan. Kedua informasi mengenai data kepatuhan dari para pelaksana terhadap peraturan dan regulasi. Pemerintah yang telah ditetapkan. Implementor harus mengetahui apakah orang lain yang terlibat didalam pelaksanaan kebijakan tersebut patuh terhadap hukum.

c. Wewenang

Pada umumnya kewenangan harus bersifat formal agar perintah dapat dilaksakan. Kewenangan merupakan otoritas atau legitimasi bagi para pelaksana dalam melaksanakan kebijakan yang ditetapan secara politik. Ketika wewenang itu nihil, maka kekuatan para implementor dimata publik tidak terlegitimasi, sehingga dapat menggagalkan proses implementasi kebijakan. Tetapi, dalam kontek yang lain, ketika wewenang formal tersebut ada, maka sering kesalahan dalam melihat efektivitas kewenangan. Disatu pihak, efektivitas kewenangan diperlukan dalam pelakasaan implementasi dalam kebijakan; tetapi disisi lain, efektivitas akan menyurut manakala wewenang diselewengkan oleh para pelaksana demi kepentingannya sendiri atau demi kepentingan kelompok.

d. Fasilitas

Fasilitas fisik merupakan faktor penting dalam implementasi kebijakan. Implementor mungkin memiliki staf yang mencukupi dan memiliki wewenang untuk melaksanakan tugasnya. Tetapi juga tanpa adanya fasilitas pendukung (sarana dan prasarana) maka implementasi kebijakan tersebut tidak akan berhasil

\section{Disposisi}

Disposisi atau sikap dari pelaksana kebijakan adalah faktor penting ketiga dalam pendekatan mengenai pelaksanaan suatu kebijakan publik, jika pelaksanaan suatu 
kebijakan ingin efektif, maka para pelaksana kebijakan tidak hanya harus mengetahui apa yang akan dilakukan tetapi juga harus memiliki kemampuan untuk melaksanakannya, sehingga dalam pratiknya tidak terjadi bias.

Hal-hal yang penting perlu di cermati pada variabel disposisi adalah:

a. Efek Disposisi

Disposisi atau sikap para pelaksana akan menimbulkan hambatan-hambatan yang nyata terhadap implementasi kebijakan bila personil ada yang tidak melaksanakan kebijakan-kebijakan yang diinginkan oleh pejabat tinggi karena itu, pemilihan dan pengangkatan personil pelaksana kebijakan haruslah orang-orang yang memiliki dedikasi pada kebijakan yang telah ditetapkan lebih khusus lagi pada kepentingan warga.

b. Melakukan pengaturan birokrasi (staffing the bureaucracy)

Dalam konteks ini mensyaratkan bahwa implementasi kebijakaan harus dilihat juga dalam hal pengaturan birokrasi. Ini merujuk pada penunjukan dan pengangkatan staf dalam birokrasi yang sesuai dengan kemampuan, kapabilitas, dan kompetensinya. Selain itu pengaturan birokrasi juga bermuara pada pembentukan sistem pelayanan publik yang optimal, penilaian personil dalam bekerja, hingga metode bypassing personil.

c. Insentif

Menyatakan bahwa salah satu teknik yang disarankan untuk mengatasi masalah kecendurungan para pelaksana dengan memanipulasi insentif. Pada umumnya orang bertindak menurut kepentingan mereka sendiri, maka memanipulasi insentif oleh pembuat kebijakan mempengaruhi tindakan pelaksana kebijakan. Dengan cara menambah keuntungan atau biaya tertentu mungkin akan menjadi faktor pendorong yang membuat para pelaksana kebijakan melaksanakan perintah dengan baik. Hal ini dilakukan sebagai upaya memenuhi kepentingan pribadi (selfinterest) atau organisasi.

4. Struktur Birokrasi

Walaupun sumber-sumber untuk melaksanakan suatu kebijakan tersedia, atau para pelaksana kebijakan mengetahui apa yang seharusnya dilakukan, dan mempunyai keinginan untuk melaksanakan suatu kebijakan kemungkinan kebijakan tersebuat tidak dapat terlaksanakan atau terrealisasi karena terdapatnya kelemahan struktur birokasi. Kebijakan yang begitu kompleks menuntut kondusif pada kebijakan yang tersedia, maka hal ini akan menyebagiankan sumberdaya-sumberdaya menjadi tidak efektif dan menghambat jalannya kebijakan. Birokrasi sebagai pelaksana sebuah kebijakan yang harus dapat mendukung kebijakan yang telah diputuskan secara politik dengan jalan melakukan koordinasi dengan baik. Dua karakteristik yang dapat mendongkrak kinerja struktur birokrasi/organisasi kearah yang lebih baik, adalah:

a. Membuat standar operating prosedures (SOPs) yang lebih fleksibel; SOPs adalah suatu prosedur atau aktivitas terencana rutin yang memungkinkan para pegawai (atau pelaksana kebijakan seperti aparatur, administratur atau birokrat) untuk melaksanakan kegiatan-kegiatannya pada tiap harinya (daysto-days politics) sesuai dengan standar yang ditetapkan (atau standar minimum yang dibutuhkan warga). 
b. Melaksanakan fragmentasi adalah upaya penyebaran tanggung jawab kegiatan-kegiatan atau aktivitas-aktivitas pegawai diantara beberapa unit kerjayang sesuai dengan bidangnya masing masing.

2) keberhasilan suatu implementasi kebijakan publik dapat diukur dari proses pencapaian outcomes (yaitu tecapai atau tidaknya tujuan yang ingin diraih). Yang mana hal ini dapat dilihat dari dua hal berikut :

1. Dilihat dari prosesnya, dengan mempertanyakan apakah pelaksanaan kebijkan sesuai dengan ditentukan (design) dengan merujuk pada aksi kebijakannya.

2. Apakah tujuan tercapai. Dimensi ini diukur dengan melihat dua faktor, yaitu :

a. Impak atau efeknya pada masyarakat secara individu atau kelompok.

b. Tingkat perubahan yang terjadi serta penerimaan kelompok sasaran dan perubahan yang terjadi.

Keberasilan suatu implementasi ditentukan oleh tingkat implementability yang terdiri atas content of policy dan context of policy.

1. Content of policy adalah :

a. Interest affected (kepentingan - kepentingan yang mempengaruhi)

Indikator ini berargumen bahwa suatu kebijakan dalam pelaksanaannya pasti melibatkan banyak kepentingan, dan sejauh mana kepentingankepentingan tersebut membawa pengaruh terhadap implementasinya.

b. Type of benefits (tipe manfaat)

Menjelaskan bahwa dalam suatu kebijakan harus terdapat beberapa manfaat yang menunjukan dampak positif yang dihasilkan pengimplementasian kebijakan yang hendak dilaksanakan.

c. Extent of change envision (derajat perubahan yang ingin dicapai)

Dijelaskan bahwa seberapa besarperubahan yang hendak atau ingin dicapai melalui suatu implementasi kebijakan harus mempunyai skala yang jelas.

d. Site of decision making (letak pengambilan keputusan)

Pengambilan keputusan dalam suatu kebijakan memegang peranan penting dalam pelaksanaan suatu kebijakan maka pada bagian ini harus dijelaskan dimana letak pengambilan keputusan dari suatu kebijakan yang akan di implementasikan.

e. Program implementor (pelaksana program)

Dalam menjalankan suatu kebijakan atau program harus didukung dengan adanya pelaksana kebijakan. Dan ini harus sudah terdataatau terpapar dengan baik.

f. Resources committed (sumber-sumber daya yang digunakan)

Pelaksanaan suatu kebijakan juga harus didukung oleh sumber-sumber daya yang mendukung agar pelaksanaannya berjalan dengan baik.

2. Context of policy adalah :

a. Power, interest, and strategy of actor involved (kekuasaan, kepentingankepentingan, dan strategi dari aktor yang terlibat)

Dalam suatu kebijakan perlu diperhitungkan pula kekuatan atau kekuasaan, kepentingan, serta strategi yang digunakan oleh para aktor yang terlibat guna memperlancar jalannya pelaksanan suatu impementasi kebijakan 
b. Institutions and regime characteristic (karakteristik lembaga dan rezim yang berkuasa)

Lingkungan dimana suatu kebijakan tersebut dilaksanakan juga berpengaruh terhadap keberhasilannya, maka pada bagian ini ingin dijelaskan karakteristik dari suatu lembaga yang akan turut mempengaruhi suatu kebijakan.

c. Compliance and responsiveness (tingkat kepatuhan dan adanya respon dari pelaksana)

Proses pelaksanan suatu kebijakan adalah kepatuahan dan respon dari pelaksana, maka yang hendak dijelaskan pada poin ini adalah sejauh mana kepatuhan dan respon dari pelaksana dalam menanggapi suatu kebijakan. Setelah pelaksanaan kebijakan yang dipengaruhi oleh isi atau konten dan lingkungan atau konteks diterapkan, maka akan dapat diketahui apakah para pelaksana kebijakan dalam membuat sebuah kebijakan sesuai dengan apa yang diharapakan, juga dapat diketahui pada apakah suatu kebijakan dipengaruhi oleh suatu lingkungan sehingga terjadinya tingkat perubahan yang terjadi.

Model Daniel H. Mazmanian \& Paul A.Sabatier

Model implementasi kebijakan yang dikemukakan oleh Mazmanian dan Sabatier disebut dengan A Framework for Policy Implementation Analysis. Model ini berpendapat bahwa peran penting dari implementasi kebijakan publik adalah kemampuannya dalam mengidentifikasikan variabel-variabel yang mempengaruhi tercapainya tujuan-tujuan formal pada keseluruhan proses implementasi. Variabel-variabel yang dimaksud dapat diklasifikasikan menjadi tiga kategori besar, yaitu:

a. Mudah tidaknya masalah yang akan digarap, meliputi: kesukaran-kesukaran teknis, keberagaman perilaku yang diatur, presentase totalitas penduduk yang tercakup dalam kelompok sasaran.

b. Tingkat dan ruang lingkup perubahan perilaku yang dikehendaki

c. Kemampuan kebijakan menstruktur proses implementasi secara tepat, meliputi : kecemasan dan kejelasan penjenjangan tujuan-tujuan resmi yang akan dicapai, keterandalan teori kausalitas yang diperlukan, ketetapan alokasi sumber dana, keterpaduan hirarki di dalam lingkungan dan diantara lembagalembaga atau intansi-intansi pelaksana, aturan-aturan pembuat keputusan dari badan-badan pelaksana, kesepakatan para pejabat terhadap tujuan yang termaktub dalam undang-undang, akses formal pihak-pihak luar.

d. Variabel-variabel dari luar undang-undang yang mempengaruhi implementasi, meliputi:

Kondisi sosial dan teknologi, dukungan publik, sikap dan sumber-sumber yang dimiliki kelompok masyarakat, kesepakatan dan kemampuan kepemimpinan para pejabat pelaksana.

Model Implementasi Thomas R. Dye

Thomas R. Dye Dalam Agustino (2017: 152 ) Model ini menganggap pelaksanaan kebijakan sebagai proses yang dinamis, karena setiap pihak yang terlibat dapat mengusulkan perubahan dalam berbagai tahap pelaksanaan. Hal itu dilakukan ketika program di anggap kurang memenuhi harapan stakeholders. Ini berarti bahwa berbagai tahap implementasi program atau kebijakan publik akan di analisis dengan 
di evaluasi oleh setiap pihak sehingga potensi, kekuatan dan kelemahan setiap fase pelaksanaanya diketahui dan segera diperbaiki untuk mecapai tujuan.

Dalam model implementasi ini meskipun persyaratan input sumber daya merupakan keharusan dalam proses implementasi kebijakan, tetapi hal itu tidak menjamin suatu kebijakan akan dilaksanakan dengan baik. Input sumber daya dapat digunakan secara optimum jika dalam proses pengambilan keputusan dan pelaksanaan kebijakan terjadi interaksi positif dan dinamis antara pengambil kebijakan, pelaksanaan kebijakan dan pengguna kebijakan (masyarakat) dalam suasana dan lingkungan yang kondusif.

Jika model interaktif implementasi kebijakan ini di sandingkan dengan model implementasi program atau kebijakan yang lain, khususnya model proses politik dan administrasi dari Grindle, terlihat adanya kesamaan dan representasi elemen yang mencirikannya. Tujuan kebijakan, program aksi, dan proyek tertentu yang dirancang dan di biayai menurut Grindle menunjukan urgensi fase pengambilan keputusan sebagai fase terpenting dalam model linier implementasi kebijakan. Sementara itu enam elemen isi kebijakan di tambah dengan tiga elemen konteks implementasi sebagai faktor yang mempengaruhi aktivitas implementasi menurut Grindle mencirikan adanya interaksi antara pengambil kebijakan, pelaksana kebijakan dan pengguna kebijakan dalam model interaktif.begitu pula istilah model proses politik dan proses administrasi menurut Grindle, selain menunjukan dominasi cirinya yang cenderung lebih dekat kepada ciri model interaktif implementasi kebijakan, juga menunjukan kelebihan model tersebut dalam cara yang digunakan untuk mengukur keberhasilan implementasi program atau kebijakan, beserta output dan outcomes-nya. Model Implementasi Horn E Metter

Horn \& Metter dalam Agustino (2017 : 133) Model pendekatan top-down merupakan sebuah abstraksi atau performasi dari suatu pelaksana kebijakan pada dasarnya secara sengaja dilakukan untuk meraih kinerja implementasi kebijakan publik yang tinggi yang berlangsung dalam hubungan dengan berbagai variabel. Model ini mengandaikan bahwa implementasi kebijakan berjalan secara linier dari keputusan politik yang tersedia, pelaksana, dan kinerja kebijakan publik.

Menurut Horn \& Metter ada enam variabel yang mempengaruhi kinerja implementasi kebijakan publik :

1. Ukuran dan Tujuan Kebijakan

Kinerja implementasi kebijakan dapat diukur tingkat keberhasilannya jika dan hanya jika ukuran dan tujuan dari kebijakan memang realistis dengan budaya sosial yang ada di level pelaksana kebijakan. Ketika ukuran kebijakan atau tujuan kebijakan terlalu ideal untuk dilaksanakan pada level warga, maka agak sulit merealisasikan kebijakan publik pada level yang dikatakan berhasil.

2. Sumber Daya

Keberhasilan proses implementasi kebijakan sangat tergantung dari kemampuan memanfaatkan sumber daya yang tersedia. Manusia merupakan sumber daya yang terpenting dalam menentukan suatu keberhasilan proses implementasi.

3. Karakteristik Agen Pelaksana

Pusat perhatian pada agen pelaksana meliputi organisasi formal dan organisasi informal yang akan terlibat dalam implementasi kebijakan publik. Hal ini 
sangat penting karena kinerja implementasi kebijakan akan sangat banyak dipengaruhi oleh ciri-ciri yang tepat serta cocok dengan para agen pelaksananya. Selain itu cakupan atau luas wilayah implementasi kebijakan juga perlu diperhitungkan manakala hendak menentukan agen pelaksana. Semakin luas cakupan implementasi kebijakan, maka seharusnya semakin besar pula agen yang dilibatkan.

4. Sikap/Kecendrungan (Disposition) Para Pelaksana

Sikap penerimaan atau penolakan dari pelaksana akan sangat banyak mempengaruhi keberhasilan atau tidaknya kinerja implementasi kebijakan. Hal ini sangat mungkin terjadi oleh karena kebijakan yang dilaksanakan bukanlah hasil formulasi warga setempat yang mengenal betul persoalan dan permasalahan yang merekarasakan.

5. Komunikasi Antar Organisasi dan Aktivitas Pelaksana

Koordinasi merupakan mekanisme yang ampuh dalam implementasi kebijakan publik. Semakin baik koordinasi komunikasi diantara pihak-pihak yang terlibat dalam suatu proses implementasi, maka asumsinya kesalahankesalahan akan sangat kecil untuk terjadi dan begitu pula sebaliknya.

6. Lingkungan Ekonomi, Sosial, dan Politik

Hal terakhir yang juga perlu diperhatikan guna menilai kinerja implementasi kebijakan adalah sejauh mana lingkungan eksternal turut mendorong keberhasilan kebijakan publik yang telah ditetapkan. Lingkungan yang dimaksud termasuk lingkungan sosial, ekonomi, dan politik. Dan lingkungan yang tidak kondusif dapat menjadi biang keladi dari kegagalan kinerja implementasi kebijakan. Oleh sebab itu, upaya untuk mengimplementasikan kebijakan harus pula memperhatikan kekondusifan kondidi eksternal.

tujuan-tujuan telah di tetapkan sesuai dengan tujuan suatu kebijakan yang telah dibuat oleh actor kebijakan tersebut. Pengertian dari enam variable menurut horn \& metter bahwa semua itu sangat mempengaruhi kinerja implementasi, yaitu standar dan sasaran kebijakan, sumber daya, komunikasi antar organisasi, karakteristik agen pelaksana, kondisi social, ekonomi politik, dan disposisi implementor. Dengan demikian masing-masing variabel merupakan factor yang signifikan yang saling mempengaruhi untuk tercapainya kinerja implementasi kebijakan tersebut.

Faktor-faktor diatas tersebut menunjukan keberhasilan dalam pelaksanaan kebijakan yang dibuat dan ditetapkan oleh pemerintah (actor kebijakan). Kebijakan tersebut dapat berhasil apabila terdapat factor-faktor tersebut dengan memberi focus pada tujuan yang sudah ditetapkan. Implemetasi kebijakan merupakan tahap yang krusial dalam proses kebijakan publik.

Model Bottom Up

Model Bottom Up adalah pendekatan dari bawah (masyarakat), pendekatan bottom up didasarkan pada jenis kebijakan publik yang mendorong masyarakat untuk mengerjakan sendiri implementasi kebijakannya atau masih melibatkan pejabat pemerintah namun hanya di tataran rendah. Model ini menyediakan suatu mekanisme untuk bergerak dari level birokrasi paling bawah, sampai pada pembuatan keputusan tertinggi di sekitar publik maupun privat. 


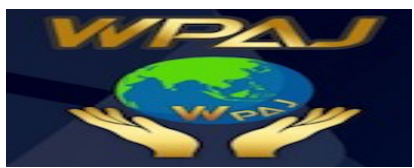

Adapun menurut adam smith dalam islamy (2001) menyatakan bahwa implementasi kebijakan dipandang sebagai suatu proses atau alur. Model ini memandang proses implementasi proses implementasi kebijakan dari presfektif kebijakan sosial dan politik, dimana kebijakan di buat oleh pemerintah bertujuan untuk mengadakan perbaikan atau perubahan dalam masyarakat sebagai kelompok sasaran.

Menurut smith implementasi kebijakan dipengaruhi oleh empat variable, yaitu:

1. Idealized Policy yaitu pola interaksi yang di gagas oleh perumus kebijakan dengan tujuan untuk mendorong, mempengaruhi dan merangsang target group untuk melaksanakannya

2. Target Groups yaitu bagian dari policy mengadopsi pola-pola interaksi sebagaimana yang diharapkan oleh perumus kebijakan. Karena kelompok ini menjadi sasaran dari implementasi kebijkan yang telah dirumuskan

3. Implementing Organization yaitu badan-badan pelaksana yang bertanggung jawab dalam implementasi kebijakan

4. Environmental factors yaitu unsur-unsur di dalam lingkungan yang mempengaruhi implementasi kebijakan seperti aspek budaya, sosial, ekonomi dan politik

Model Elmore, Lipsky, Hjem \& O'porter dalam Kadji (2015:61) menegaskan bahwa "Model ini di mulai dari mengidentifikasi jaringan aktor yang terlibat di dalam proses pelayanan dan menanyakan kepada mereka: tujuan,strategi, aktivitas, dan kontakkontak yang mereka miliki". Pada prinsipnya model implementasi ini di dasarkan pada tahapan-tahapan, yakni :

a. Mengidentifikasi jaringan aktor yang terlibat

b. Jenis kebijakan publik yang mendorong masyarakat untuk mengerjakan sendiri implementasi kebijakannya, atau masih melibatkan pejabat pemerintah di level terbawah

c. Kebijakan yang dibuat sesuai dengan harapan, keinginan publik yang menjadi target

d. Prakarsa masyarakat secara langsung atau melalui lembaga swadaya masyarakat Model ini juga mengedepankan dua variabel utama, yaitu:

1. Content of policy \& contex implementation, meliputi:

a. Kepentingan yang terpengaruhi oleh kebijakan

b. Jenis manfaat yang akan di hasilkan

c. Derajat perubahan yang diinginkan

d. Kedudukan pembuat kebijakan

e. Pelaksana program

f. Sumber daya yang dikerahkan.

2. Dampak (impact) dari kebijakan itu sendiri,meliputi :

a. Manfaat dari program

b. Perubahan dan peningkatan kehidupan kepada masyarakat

\section{Metode Penelitian}

Dalam penelitian ini peneliti mengelola data yang bersifat deskriptif seperti mengelolah transkripsi wawancara, catatan lapangan, gambar, foto, dan lain-lain. Selain itu peneliti juga menekankan pada pentingnya kedekatan dengan orang-orang dan situasi peneliti agar peneliti memperoleh pemehaman jelas tentang realitas dan 


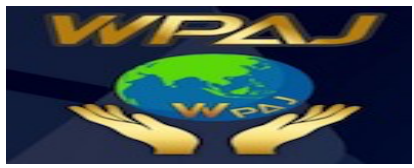

Volume 2 Issue 2, Desember 2020

http://ejournal.unsub.ac.id/index.php/publik

kondisi kehidupan nyata. Digunakannya metode deskriptif dengan pendekatan kualitatif, dimaksudkan untuk membuat deskripsi, gambaran secara sistematis, factual, dan akurat mengenai suatu obyek, suatu kondisi pada masa sekarang serta hubungan antar fenomena yang diteliti.

Tujuan peneliti memilih metode deskriptif kualitatif ialah untuk memahami fenomena atau gejala sosial dengan lebih menitik beratkan pada gambaran yang lengkap tentang fenomena yang dikaji dari pada merincinya menjadi variabelvariabel yang saling terkait. Harapannya ialah diperoleh pemahaman yang mendalam tentang fenomena untuk selanjutnya dihasilkan.

\section{Hasil dan Pembahasan}

Dinas Penanaman Modal Dan Pelayanan Terpadu Satu Pintu Kabupaten Subang Dengan dikeluarkannya Peraturan Pemerintah Nomor 18 Tahun 2016 tentang Perangkat Daerah, Peraturan Daerah Kabupaten Subang Nomor 7 Tahun 2016, tentang Pembentukan dan Susunan Perangkat Daerah Kabupaten Subang, dan Peraturan Bupati Kabupaten Subang Nomor 32 Tahun 2016, tentang Susunan Organisasi Perangkat Daerah Dinas, maka sejak 1 Januari 2017 Badan Penanaman Modal dan Perizinan (BPMP) berubah nomenklatur menjadi Dinas Penanaman Modal dan Pelayanan Terpadu Satu Pintu (DPMPTSP). DPMPTSP mempunyai tugas pokok membantu Bupati dalam melaksanakan urusan pemerintahan di Bidang Penanaman Modal dan Pelayanan Terpadu Satu Pintu yang menjadi kewenangan daerah dan tugas pembantuan yang diberikan kepada pemerintah kabupaten.

DPMPTSP memiliki fungsi :

1. Perumusan kebijakan teknis di Bidang Penanaman Modal dan Pelayanan Terpadu Satu Pintu

2. Penyelenggaraan urusan pemerintahan dan pelayanan umum di Bidang Penanaman Modal dan Pelayanan Terpadu Satu Pintu sesuai dengan ketentuan yang ditetapkan oleh Bupati.

3. Pembinaan dan pelaksanaan kegiatan di Bidang Penanaman Modal dan Pelayanan Terpadu Satu Pintu.

4. Pengelolaan administrasi umum, meliputi urusan perencanaan, evaluasi dan pelaporan, urusan umum dan kepegawaian, urusan keuangan dan barang daerah.

Pada Bulan Desember 2017, DPMPTSP telah me-launching Perizinan secara Online yang diresmikan oleh Plt. Bupati Subang, Imas Aryumningsih. Pelayanan perizinan secara online telah diimplementasikan dan dikembangkan secara terus menerus demi kemudahan investasi di Kabupaten Subang.

Visi misi setiap dinas di kabupaten subang secara kesulurahan ialah sama yaitu mengacu pada visi dan misi kabupaten subang adapun visi dari kabupaten subang ialah "Kabupaten Subang Yang Bersih, Maju, Sejahtera dan Berkarakter".

Visi tersebut di atas memiliki makna yang sangat dalam, mendasar serta strategis, sebagai landasan bagi seluruh masyarakat dalam melaksanakan pembangunan di Kabupaten Subang di satu sisi. Disisi lain merupakan target capaian yang menjadi keinginan dan cita-cita serta impian yang akan diwujudkan oleh Bupati dan Wakil Bupati selama (lima) tahun kedepan. Dari perspektif inilah, visi tersebut memiliki makna yang dalam, yaitu : 
a. Bersih yang berarti Pemerintah yang bersih dari Korupsi, Kolusi dan Nepotisme, Profesional dan Proposional dengan mengedepankan pelayanan kepada masyarakat,serta pemerintahan dan masyarakat yang religius;

b. Maju yang berarti Masyarakat Subang meningkat dalam segi kualitas hidup, menikmati standar hidup layak, melalui pembangunan yang adil dan merata;

c. Sejahtera yang berarti Masyarakat Subang memiliki rata-rata tingkat pendapatan yang memadai, tingkat pendidikan yang cukup, derajat kesehatan yang baik, kehidupan yang aman dan nyaman, sehingga dapat hidup yang layak baik secara fisik maupun non fisik;

d. Berkarakter yaitu Masyarakat Subang yang memiliki ciri khas budaya dan kearifan lokal dalam setiap sendi kehidupan, ditunjang dengan keteguhan iman dan ketaqwaan kepada Allah Swt.

Rumusan misi disusun dengan memperhatikan faktor -faktor lingkungan strategis, baik eksternal dan internal yang mempengaruhi sertakekuatan, kelemahan, peluang dan tantangan yang ada dalam pembangunan daerah. Misi disusun untuk memperjelas jalan atau langkah yang akan dilakukan dalam rangka mencapai perwujudan visi. Untuk mewujudkan Visi diatas, maka disusunlah lima misi yang kemudian disebut "Panca Jimat - Akur untuk Subang JAWARA"yaitu :

1. Mewujudkan pemerintahan yang bersih dari korupsi, kolusi, dan nepotisme, terbuka, serta pelayan masyarakat.

2. Meningkatkan pembangunan infrastruktur, penataan ruang berkarakter kebudayaan lokal dan pemerataan pembangunan perdesaan.

3. Meningkatkan kualitas pendidikan untuk menciptakan sumber daya manusia yang handal dan berdaya saing serta perluasan lapangan kerja.

4. Meningkatnya kesejahteraan masyarakat melalui pembangunan bidang pertanian, ekonomi kerakyatan, industri kreatif, perikanan dan kelautan, serta penggalian potensi berbasis budaya dan kearifan lokal.

5. Meningkatkan kualitas layanan kesehatan masyarakat dan lingkungan hidup. Adapun visi dari dinas penanaman modal dan pelayanan terpadu satu pintu di kabupaten subang termasuk pada program jawara ke Sembilan yaitu jawara nagara yang dimana meliputi reformasi birokrasi dan hukum. Disamping itu dinas penanaman modal dan pelayanan terpadu satu pintu kabupaten subang memiliki visi dan misi tersendiri yaitu "Terciptanya Kemandirian Ekonomi Daerah dan Pelayanan Terpadu yang cepat, mudah dan Transparan". Serta Misi dari Dinas Pelayanan Terpadu Satu Pintu Kabupaten Subang Ialah :

1. Terciptanya kemandirian ekonomi daerah

2. Terwujudnya pelayanan terpadu satu pintu yang cepat, mudah dan transparan Dinas penanaman modal dan pelayanan terpadu satu pintu kabupaten subang juga memiliki motto: Simple, Normatif, Akuntabel, Akurat, Satisfie (SINANAS) serta memiliki Maklumat Layanan yaitu:

"dengan ini kami menyatakan sanggup menyelengarakan pelayanan sesuai standar pelayanan yang telah diterapkan dan apabila kami tidak menepati janji ini, kami siap menerima sanksi sesuai dengan peraturan perundang-undangan yang berlaku" 


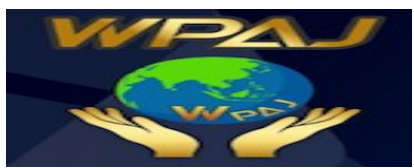

Volume 2 Issue 2, Desember 2020

http://ejournal.unsub.ac.id/index.php/publik

Implementasi kebijakan sistem online single submission (OSS) pada dinas penanaman modal dan pelayanan terpadu satu pintu di kabupaten subang

Menurut Horn \& Metter dalam Agustino (2017 : 133) performasi dari suatu pelaksana kebijakan pada dasarnya secara sengaja dilakukan untuk meraih kinerja implementasi kebijakan publik yang tinggi yang berlangsung dalam hubungan dengan berbagai variabel. Model ini mengandaikan bahwa implementasi kebijakan berjalan secara linier dari keputusan politik yang tersedia, pelaksana, dan kinerja kebijakan publik. Menurut Horn \& Metter ada enam variabel yang mempengaruhi kinerja implementasi kebijakan publik :

1. Ukuran dan tujuan kebijakan

2. Sumber daya

3. Karakteristik agen pelaksana

4. Sikap dan kecenderungan (disposition) para pelaksana

5. Komunikasi antar organisasi dan aktivitas pelaksana

6. Lingkungan ekonomi, sosial dan politik

Dengan menggunakan teknik wawancara dengan informan dalam bentuk observasi langsung Implementasi kebijakan sistem Online Single Submission (OSS) pada Dinas Penanaman Modal Dan Pelayanan Terpadu Satu Pintu Di Kabupaten Subang peneliti mengumpulkan data-data seperti data primer dan data sekunder untuk kemudian peneliti analisis lebih dalam. Analisis ini berfokus pada pelaksana dan penerima kebijakan dikaitkan dengan beberapa unsur atau identifikasi masalah.

Untuk memperkuat kajian masalah tersebut, maka berikut ini peneliti akan menguraikan pembahasan terhadap masing-masing dimensi yang terdiri dari beberapa indikator dari variable kebijakan yang diperoleh dari hasil wawancara, pengamatan, serta diperkuat oleh dokumentasi berupa foto dan rekaman. hasil ini membahas mengenai implementasi kebijakan sistem online single submission pada dinas penanaman modal dan pelayanan terpadu satu pintu di kabupaten subang sebagai berikut :

\section{Ukuran Dan Tujuan Kebijakan}

Menurut Horn \& Metter Dalam Agustino (2017 : 133) Kinerja implementasi kebijakan dapat diukur tingkat keberhasilannya jika dan hanya jika ukuran dan tujuan dari kebijakan memang realistis dengan budaya sosial yang ada di level pelaksana kebijakan. Ketika ukuran kebijakan atau tujuan kebijakan terlalu ideal untuk dilaksanakan pada level warga, maka agak sulit merealisasikan kebijakan publik pada level yang dikatakan berhasil.

1) Target pencapaian

Dalam pegimplemtasian sistem online single submission dinas penanaman modal dan pelayanan terpadu satu pintu telah mengimplementasikan sistem tersebut pada saat peraturan presiden di tetapkan yaitu pada juni 2018 sesuai dengan perintah dari pemerintah pusat.

Berikut pemaparan dari Ibu Risty Wulandari ST.,MT selaku kepala seksi pengembangan sistem informasi : " untuk target pengimplementasian sih ingin secepatnya ya, karena kan kalau sudah terimplementasikan dengan baik kerjaan kita juga agak berkurang, kalau sekarang sih masih nunggu anggran dulu soalnya kan kita juga butuh dana buat nambah fasilitas kaya computer dkk. Insya allah tahun 2020 


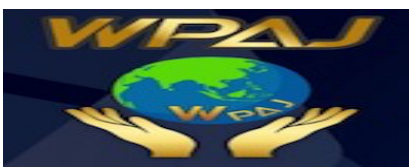

sudah terimplemntasikan ". Selanjutnya peneliti coba mewawancarai Bapak Hendri Winata selaku pelaksana seksi pengembangan sistem informasi, berikut pemaparannya : "target sih 2020 ya, cuman kita juga terhambat karena sistem OSS yang pemerintah luncurkan ini belum sepenuhnya sempurna, kemarin aja baru peningkatan versi dari versi 0,00 jadi 0,01 tapi itu pun masih uji coba jadi belum sepenuhnya sempurna, kan bingung nerapinnya gimana sistemnya saja belum bener tapi harus di pake peningkatan versi itu pun belum sempurna karna apa, misal kita sudah buat NIB di versi 0,00 pas kita masuk dengan versi 0,01 data kita ga ada jadi pelaku usaha pun tidak bisa mengakses NIB nya jadi di versi 0,01 ini tidak memuat data yang ada di versi $0,00^{\prime \prime}$.

2) Proses integrasi sistem online single submission

Dalam proses pengimplementasian sistem online single submission masih banyak hal-hal yang perlu di benahi. Berikut pemaparan dari Ibu Risty Wulandari ST.,MT selaku kepala seksi bagian pengembangan sistem informasi : " kalau dari proses nya sih lancar ya alhamdulilah ya mungkin ada beberapa aja yang bikin pusing karena emang sistemnya aja belum siap tapi harus tetep di pake kan gini ya kita kan punya berbagai macam izin, nah itu harus di ringkas dalam satu aplikasi dan itu diringkasnya untuk seluruh Indonesia sedangkan tiap daerah itu punya kebijakan masing-masing punya izin nya beda-beda gak akan sama semua kan ribet". Peneliti juga coba mewawancarai Bapak Hendri Winata selaku pelaksana seksi pengembangan sistem informasi, berikut pemaparannya : " bicara proses sih lancarlancar aja ya Cuma kita masih perlu koordinasi dengan diskominfo karena kita masih belum menggunakan aplikasi si-cantik karena kan syarat-syarat nya masuk kesana nanti keluar dan masuk di bantu aplikasi si-mantra begitu proses nya tapi kita masih coba masukin dulu ke aplikasi yang kita punya ". Peneliti juga mencoba mewawancari beberapa informan dari masyarakat berikut pemaparan dari ibu yeni selaku pelaku usaha : "proses pembuatan izin yang sekarang tuh bikin ribet ya harus punya NIB segala macem dulu lah, terus kita juga harus punya izin-izin yang lain dulu kaya izin lingkungan dll juga, belum lagi nnti harus scan dulu terus upload di aplikasi kalo untuk masyarakat awam kan susah de, apalagi yang gagap teknologi gitu harus gimana coba".

Dari hasil observasi yang dilakukan pihak DPMPTSP sedang mengupayakan pengimplementasian sistem OSS dari mulai mempersiapkan sarana dan prasana yang di butuhkan untuk penerapan sistem tersebut jika di hubungkan dengan teori horn \& metter untuk variable ukuran dan tujuan kebijakan tersebut sudah ada akan tetapi belum terimplementasi secara optimal.

\section{Sumber Daya}

Menurut Horn\& Metter dalam Agustino (2017:134) Keberhasilan proses implementasi kebijakan sangat tergantung dari kemampuan memanfaatkan sumber daya yang tersedia. Manusia merupakan sumber daya yang terpenting dalam menentukan suatu keberhasilan proses implementasi.

1) Fasilitas

Dalam hal sumber daya fasilitas sarana dan prasarana menjadi hal penting dalam pencapaian proses implementasi. Berikut pemaparan dari Ibu Risty Wulandari ST.,MT selaku kepala seksi bagian pengembangan sistem informasi : " kalau dari 


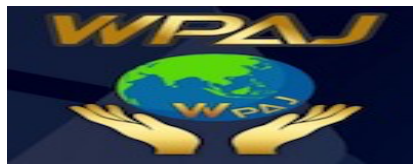

fasilitas udah cukup ya, cuman akan ada penambahan beberapa fasilitas aja kaya sekarangkan lagi ada renovasi di gedung pelayanan sebelah sana". Peneliti juga coba mewawancarai Bapak Hendri Winata selaku pelaksana seksi pengembangan sistem informasi, berikut pemaparannya : "fasilitas sih kita sudah siap ya, cuman nanti kita kan tambah kaya computer dan lain-lain, kaya computer yang layar sentuh gitu untuk mempermudah pelaku usaha dalam pembuatan izin, tapi bukan izin usaha saja ya tapi untuk semua proses perizinan". Peneliti juga mencoba mewawancarai beberapa masyarakat berikut pemaparannya ibu yeni selaku pelaku usaha : "kalau fasilitasnya sih baik ya tapi tetep aja kalau untuk masyarakat awam kan susah, apa lagi ini pake internet-internet gitu ". Berikut pula pemaparan dari ibu ii selaku pelaku usaha : " fasilitas sih udah baik sih ya aku sih udah kebantu juga, kalau daftar gitu kan aku udah ada computer di rumah cuman kalo ada kendala gitu aku tanyain aja ke pihak dpmptsp“

\section{2) Sumber daya manusia}

Dalam proses implementasi kebijakan sumber daya manusia merupakan hal yang memperngaruhi proses implementasi. Berikut pemaparan dari Ibu Risty Wulandari ST.,MT selaku kepala seksi bagian pengembangan sistem informasi : " kalau sumber daya sih udah cukup ya, kan yang penting orang bisa bikin akun sendri dulu aja dia pasti bisa mengoprasikan OSS juga ". Peneliti juga coba mewawancarai Bapak Hendri Winata selaku pelaksana seksi pengembangan sistem informasi, berikut pemaparannya: "saya rasa kalau dari SDM memang masih kurang ya, soalnya orangorangnya juga masih harus di latih dulu, nanti kita juga akan melakukan pelatihan untuk nanti orang-orang yang akan diam atau stay di depan sebagai pemberi pelayanan kalau nanti yang mengoprasikannya aja ga bisa terus masyarakat gimana dong". Peneliti juga mencoba mewawancarai beberepa masyarakat berikut pemaparannya ibu yeni selaku pelaku usaha : "kalau dalam pelayanan sih udah baik ya, kayanya aku yang salah Tanya orang atau gimana, tadi Tanya masalah OSS dianya bilang suruh Tanya ke sana aja, gitu". Berikut pula pemaparan dari ibu ii selaku pelaku usaha : "kalau aku sih cukup terbantu lah ya sekarang kan izin yang aku buat juga udah mau selesai".

Dari hasil observasi yang dilakukan jika dilihat dari teori Horn \& Metter pada variable sumber daya pihak DPMPTSP telah memiliki sumber daya fasilitas yang cukup memadai seperti komputer, internet, dan lain-lain untuk membantu para pelaku usaha dalam pembuatan izin akan tetapi bicara mengenai sumber daya manusia yang dimiliki pihak DPMPTSP masih belum memadai, hal tersebut di akui oleh pihak DPMPTSP karena masih banyak petugas dari pihak DPMPTSP yang masih harus dilatih terlebih dahulu untuk mengoprasikan sistem OSS karena tidak semua petugas memahami betul tentang tata cara pengoprasian sistem OSS itu sendiri. Pihak DPMPTSP menambahkan bahwa pihaknya akan mengadakan pelatihan khusus untuk para petugas terutama petugas-petugasyang berada di depan yang langsung melayani masyarakat, pihaknya akan mengadakan pelatihan dengan mendatangkan petugas dari lembaga OSS pusat".

\section{Karakteristik Agen Pelaksana}


Menurut Horn\& Metter dalam Agustino (2017:134) Pusat perhatian pada agen pelaksana meliputi organisasi formal dan organisasi informal yang akan terlibat dalam implementasi kebijakan publik. Hal ini sangat penting karena kinerja implementasi kebijakan akan sangat banyak dipengaruhi oleh ciri-ciri yang tepat serta cocok dengan para agen pelaksananya. Selain itu cakupan atau luas wilayah implementasi kebijakan juga perlu diperhitungkan manakala hendak menentukan agen pelaksana. Semakin luas cakupan implementasi kebijakan, maka seharusnya semakin besa pula agen yang dilibatkan. Berikut pemaparan dari Ibu Risty Wulandari ST.,MT selaku kepala seksi bagian pengembangan sistem informasi : “ kriteria khusus sih ga ada yah, yang penting dia nya mau belajar aja. Udah “. Peneliti juga mencoba mewawancarai beberepa masyarakat berikut pemaparannya ibu yeni selaku pelaku usaha : " saya sih taunya pas seminar di kasih tau cara-cara mengisi pengaplikasian perizinan online “.

\section{Sikap Atau Kecenderungan (Disposition) Para Pelaksana}

Menurut Horn\& Metter Dalam Agustino (2017:135) Sikap penerimaan atau penolakan dari pelaksana akan sangat banyak mempengaruhi keberhasilan atau tidaknya kinerja implementasi kebijakan. Hal ini sangat mungkin terjadi oleh karena kebijakan yang dilaksanakan bukanlah hasil formulasi warga setempat yang mengenal betul persoalan dan permasalahan yang merekarasakan. Berikut pemaparan dari Ibu Risty Wulandari ST.,MT selaku kepala seksi bagian pengembangan sistem informasi : kalau bicara soal pelayanan kita semua disi sama ratakan ya sesuai kebutuhan dia apa keperluan dia apa kita akan layani sesuai SOP yang di terapakan “. Peneliti juga coba mewawancarai bapak hendri winata selaku pelaksana seksi pengembangan sistem informasi, berikut pemaparannya : " cara pelayanan sih sama yah harus tetep lewat OSS dulu kan , baru kalau OSS nya selesai bisa maju ke tahap berikutnya “. Peneliti juga mencoba mewawancarai beberepa masyarakat berikut pemaparannya ibu yeni selaku pelaku usaha : " keramahan petugas sih ramah ya, sopan santun nya juga bagus ". Berikut pula pemaparan dari ibu ii selaku pelaku usaha : " kalau siap pelayanan sih udah baik ya, suka membatu juga kalu sya ga ngerti terus saya whatsapp ibunya, di jawab, gitu aja sihh". Sikap atau kecenderungan para pelaksana sangat mempengaruhi dalam proses pelayanan, dilihat dari sikap yang diberikan oleh para petugas DPMPTSP sudah cukup baik dari mulai menjelaskan tata cara pembuatan izin serta mendengarkan semua kendala-kendala pembuatan izin dari para pelaku usaha.

\section{Komunikasi Antar Organisasi}

Menurut Horn\& Metter Dalam Agustino (2017:135) Koordinasi merupakan mekanisme yang ampuh dalam implementasi kebijakan publik. Semakin baik koordinasi komunikasi diantara pihak-pihak yang terlibat dalam suatu proses implementasi, maka asumsinya kesalahan-kesalahan akan sangat kecil untuk terjadi dan begitu pula sebaliknya. Berikut pemaparan dari ibu risty wulandari ST.,MT selaku kepala seksi bagian pengembangan sistem informasi : " hubungan antar organisasi sih kita terhubung ya sama dinas-dinas yang lain terbuka juga masalah informasi tentang OSS ini intinya sih kita kerjasama sama semua dalam proses 


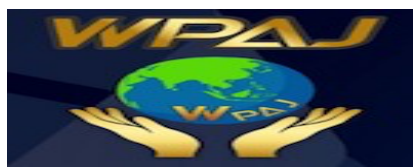

pengimplementasian sistem ini “. Peneliti juga coba mewawancarai bapak hendri winata selaku pelaksana seksi pengembangan sistem informasi, berikut pemaparannya : " komunikasi sih pasti harus ya kita juga udah sebar luaskan masalah OSS ini ke setiap dinas-dinas yang bersangkutan nanti juga kedepannya kita akan adakan seminar untuk masalah OSS ini nanti undang perwakilan dari dinas-dinas yang lain terus LSM-LSM juga gitu." Peneliti juga mencoba mewawancarai beberepa masyarakat berikut pemaparannya ibu yeni selaku pelaku usaha : "saya sih tau nya soal OSS dari dinas kesehatan terus dari dinas penanaman modal juga, informasinya sih cukup jelas sih ya ." Berikut pula pemaparan dari ibu ii selaku pelaku usaha : " taunya sih dari dinas ini ya (DPMPTSP) kan mau buat izin terus di kasih tau harus punya NIB dulu,dll. Infonya sih cukup jelas “

Jika dihubungkan dengan teori Horn \& Metter komunikasi antar organisasi merupakan mekanisme yang ampuh dalam implementasi kebijakan publik, dari hasil observasi yang dilakukan pihak DPMPTSP sangat terbuka kepada setiap dinas-dinas yang bersangkutan tentu hal tersebut mempermudah dalam penerapan sistem OSS itu sendiri.

\section{Lingkungan Ekonomi, Sosial Dan Politik}

Menurut Horn\& Metter Dalam Agustino (2017:135) guna menilai kinerja implementasi kebijakan adalah sejauh mana lingkungan eksternal turut mendorong keberhasilan kebijakan publik yang telah ditetapkan. Lingkungan yang dimaksud termasuk lingkungan sosial, ekonomi, dan politik. Dan lingkungan yang tidak kondusif dapat menjadi biang keladi dari kegagalan kinerja implementasi kebijakan. Oleh sebab itu, upaya untuk mengimplementasikan kebijakan harus pula memperhatikan kekondusifan kondidi eksternal.

Berikut pemaparan dari Ibu Risty Wulandari ST.,MT selaku kepala seksi bagian pengembangan sistem informasi : " hamabatan sih masih dari sistemnya aja ya, harusnya pemerintah perbaiki dulu sempurnakan dulu baru keluarin peraturannya, bukan peraturannya di keluarin dulu tapi sistemnya masih belum siap, kalau dari lingkungan sih aman -aman aja ya asl kita menginfokannya jelas prosesnya juga gampang masyarakat pasti ikut, kalau sekarangkan jadi malah makin ribet masyarakat juga nantinya malah bingung." Peneliti juga coba mewawancarai bapak hendri winata selaku pelaksana seksi pengembangan sistem informasi, berikut pemaparannya : " ya paling itu sistemnya aja yang harus di benahi dulu kalau tujuan peng implementasiannya ingin tercapai, tujuannya kan ingin mempermudah masyarakat dimana pun berada ingin buat izin apapun dimana pun hanya cukup butuh satu aplikasi aja beres. Kan setiap pelaku usaha harus punya NIB dan NIB itu di buatnya melalui OSS kalau OSS nya belum siap gimana kan sekarang juga setiap orang yang mengajukan pinjaman ke bank-bank gitu yang ngajuin jaminan usaha harus punya NIB kalu NIB aja ga punya ya ga akan di proses". Peneliti juga mencoba mewawancarai beberepa masyarakat berikut pemaparannya ibu yeni selaku pelaku usaha: " ribet ya, prosesnya juga jadi tambah lama, harusnya nih yah proses pembuatan izin usaha tuh dibikin mudah aja soalnya kan ga semua pengusaha itu pinter tau teknologi, kalau emang diharuskan melalui online jangan terlalu banyak persyaratan yang harus di ajukan seperti IMB. Bagaimana kalau status tempat usahanya sewa kontrak sedangkan pemilik tempat enggan mengurusi IMBnya." 


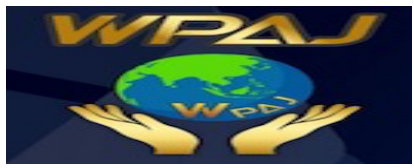

Berikut pula pemaparan dari ibu ii selaku pelaku usaha : "kalau menurut saya sih mudah aja kalau persyaratannya lengkap semua." Dari hasil observasi yang dilakukan pengimplementasian sistem OSS tidak ada hambatan kecuali hambatan dari sistemnya itu sendiri, sistem yang belum sempurna dan harus di implementasikan secepat mungkin menjadi suatu tantangan bagi pihak DPMPTSP dalam proses peng integrasian sistem tersebut. Berdasarkan pemaparan di atas penerapan sistem online single submission belum efektif karena masih banyaknya kendala yang dihadapi oleh para pengelola sistem OSS dan serta masih banyak masyarakat yang belum paham terhadap penggunaan sistem OSS tersebut.

\section{Kesimpulan}

Berdasarkan pembahasan dari hasil penelitian yang telah disajikan, dapat disimpulkan bahwa implemantasi kebijakan sistem online single submission pada dinas penanaman modal dan pelayanan terpadu satu pintu di kabupaten subang belum efektif , karena belum terpenuhinya unsur-unsur di bawah ini :

Dilihat dari indikator ukuran dan tujuan kebijakan implementasi online single submission belum efektif karena masih banyak kendala yang menjadi hambatan penerapan sistem OSS seperti belum sempurnanya sistem tersebut untuk di gunakan dan masih dalam tahap penyempurnaan agar dapat mencapai tujuan yang di inginkan.

Sumber daya yang ada di dinas penanaman modal dan pelayanan terpadu satu pintu kabupaten subang sudah cukup siap untuk penerapan sistem OSS.

Dalam pemilihan agen pelaksana tidak ada keriteria khusus yang harus di penuhi karena dalam hal pengintegrasian serta sosialisasi mengenai sistem OSS di lakukan oleh pihak dinas penanaman modal dan pelayanan terpadu satu pintu kabupaten subang sendiri. Jadi jika di kaitkan dengan teori horn \& metter mengenai kriteria khusus agen pelaksana untuk membantu pengintegrasian sistem OSS sudah cukup optimal.

Sikap/Kecendrungan (Disposition) Para Pelaksana; setiap petugas selalu melayani dengan sikap yang sopan serta ramah kepada masyarakat yang datang, Jika di kaitkan dengan teori horn \& metter sikap atau kecenderungan para pelaksana dinas penanaman modal dan pelayanan terpadu satu pintu kabupaten subang dapat di katakana optimal.

Komunikasi Antar Organisasi dan Aktivitas Pelaksana; Dalam hal komunikasi antar organisasi pihak dinas penanaman modal dan pelayanan terpadu satu pintu di kabupaten subang sudak cukup baik untuk membantu peng integrasian sistem OSS seperti memberikan informasi mengenai sitem OSS kepada setiap dinas yang bersangkutan dan dinas yang telah di informasikan akan menginformasikan kembali kepada masyarakat yang berkepentingan untuk pembuatan izin dll.

Lingkungan Ekonomi, Sosial, dan Politik; Dalam lingkungan sosial ekonomi dan politik pengimplemantasian sistem OSS sudah diterima dengan baik namun lingkungan masyarakat yang awam akan teknologi menjadi kendala tersendiri untuk proses penerapan sistem tersebut. 


\section{Referensi}

Abdul Wahab, Solichin. 2004.Analisis Kebijaksanaan Dari Formulasi Ke Implementasi Kebijaksanaan Negara.Jakarta:Bumi Aksara.

Anggara, Sahya. 2014. Kebijakan Publik. Bandung : Pustaka Setia.

Agustino,Leo.2008.Dasar-Dasar Kebijakan Publik.Bandung:Alfabeta.

Agustino,Leo.2017.Dasar-Dasar Kebijakan Publik.Bandung:Alfabeta.

Budiman Rusli M.S.2015.Kebijakan Publik Membangun Pelayanan Publik Yang Responsif.Bandung:Hakim Publishing.

Budi Winarno.2007.Kebijakan Publik Teori Dan Proses Edisi Revisi.Yogyakarta:Media Presindo.

Budi Winarno.2012. Kebijakan Publik Teori Proses Dan Studi Kasus.Yogyakarta:CAPS.

Indiahono, Dwiyanto. 2009. Kebijakan Publik Berbasis Dynamic Policy Analysis.Yogyakarta:Gava Media.

Islamy,M.Irfan.2001.Prinsip- Prinsip Perumusan Kebijakan Negara.Jakarta:Bumi Aksara

Islamy,M.Irfan.2003.Prinsip- Prinsip Perumusan Kebijaksanaan Negara.Jakarta:Bumi Aksara

Moleong, Lexy.2000. Metode Penelitian Kualitatif. Bandung: Remaja Rosdakarya

Mulyadi,Deddy.2015.Perilaku Organisasi Dan Kepemimpinan Pelayanan.Bandung:Alfabeta

Nugroho, Riant. 2013. Metode Penelitian Kebijakan.Yogyakarta:Pustaka Pelajar.

Subarsono.2010.Dasar-Dasar Kebijakan Publik Konsep Teori Aplikasi.Yogyakarata:UNY Press.

Sugiyono.2015.Metode Penelitian Kuantitatif Kualitatif Dan RED.Bandung:Alfabeta.

Tangkilisan, Hessel Nogi. 2003. Kebijakan Publik Yang Membumi. Yogyakarta: Lukman Offset YPAPL

Usman,Husani.\& Setiady Akbar,Purnomo.2014.Metodelogi Penelitian Sosial.Jakarta:Bumi Aksara

Yulianto Kadji.2015.Formulasi Dan Implementasi Kebijakan Publik.Gorontalo:UNG Press.

Widodo, Joko. 2011. Analisis Kebijakan Publik: Konsep dan Aplikasi Analisis Proses Kebijakan Publik. Malang : Bayu Media

Peraturan Presiden Republik Indonesia Nomor 24 Tahun 2018 Tentang Pelayanan Perizinan Berusaha Terintegrasi Secara Elektronik

Permendag Nomor 76 Tahun 2018 tentang Penyelenggaraan Pendaftaran Perusahaan

Permendag Nomor 77 Tahun 2018 tentang Pelayanan Perizinan Berusaha Terintegrasi Secara Elektronik Di Bidang Perdagangan 


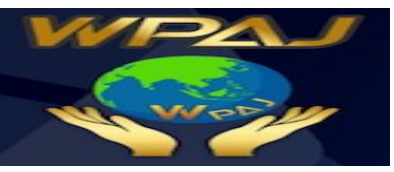

Volume 2 Issue 2, Desember 2020 http://ejournal.unsub.ac.id/index.php/publik

Permenkes Nomor 26 Tahun 2018 tentang Pelayanan Perizinan Berusaha Terintegrasi Secara Elektronik Sektor Kesehatan

Permen LHK RI Nomor: P.26/MENLHK/SETJEN/KUM.1/7/2018 tentang Pedoman Penyusunan dan Penilaian Serta Pemeriksaan Dokumen Lingkungan Hidup Dalam Pelaksanaan Pelanyanan Perizinan Berusaha Terintegrasi Secara Elektronik

https://oss.go.id/oss/\#

https://dpmptsp.subang.go.id/

Pedoman Perizinan Berusaha Melalui Sistem Oss Untuk Pelaku Usaha

Standar Pelayanan Pada Dinas Penanaman Modal Dan Pelayanan Terpadu Satu Pintu Kabupaten Subang 